\title{
Esophagus and Esophagogastric Junction Cancer TNM Finding v7
}

National Cancer Institute

\section{Source}

National Cancer Institute. Esophagus and Esophagogastric Junction Cancer TNM Finding v7. NCI Thesaurus. Code C89720.

A finding about one or more characteristics of esophagus and esophagogastric junction cancer, following the rules of the TNM AJCC V7 classification system. Tumor location is simplified, and esophagog astric junction and proximal $5 \mathrm{~cm}$ of stomach are included in this classification. Nonmucosal cancers are not included. (from AJCC 7th Ed.) 